\title{
Adaptation and Growth of Botryococcus braunii on Acid Mine Drainage
}

\author{
Fransiscus Benhardi Wastuwidya, Setyo Sarwanto Moersidik
}

\begin{abstract}
Phycoremediation of acid mine drainage (AMD) is an alternative to AMD treatment but has limited applications. The obstacle in the application of AMD phycoremediation is that the characteristic of wastewater which limits the growth of microalgae, where AMD has a high metal content and low pH. In this study, Botryococcus braunii was cultured on media with variations in the addition of AMD of (v/v) 0\%, 2.5\%, 3\%, 3.5\%, $4 \%$ and had a pH of 7.2, 5.6, 5.1, 4.8, 4.3, respectively, on the photobioreactor. Botryococcus braunii growth rate was analyzed, as well as the effect of metal exposure and $\mathrm{pH}$ variations on the growth of Botryococcus braunii. Botryococcus braunii showed different growth rates, sequentially from the highest rate in the media with addition of AMD (v/v) 2.5\%, 3\%, $0 \%, 3.5 \%, 4 \%$ is $1.403 d^{-1}, 1.374 d^{-1}, 0.0862 d^{-1}, 0.0738 d^{-1}$, and $0.0616 d^{-1}$. It is known that the highest growth rate of Botryococcus braunii is obtained in media with $2.5 \%(v / v)$ AMD with an initial pH of 5.6, and Fe and Mn concentrations of 2.15 $m g . L^{-1}$ and $0.62 \mathrm{mg} . L^{-1}$, respectively. It is also known the ability of Botryococcus braunii to adapt to acidic conditions with Fe and Mn content, where Botryococcus braunii plays a role in increasing media $\mathrm{pH}$ and is able to remove $\mathrm{Fe}$ and $\mathrm{Mn}$ with the highest values of $84.28 \%$ and $98 \%$, respectively.
\end{abstract}

Keywords: AMD, bioremediation, microalgae, mining, phycoremediation.

\section{INTRODUCTION}

Acid mine drainage (AMD) is wastewater from mining or mine processing activity that has high acidity and are formed as a result of oxidation of sulfide minerals exposed to the atmosphere in excavation and stockpiling. AMD is caused by mining residual products that are rich in sulfides, usually found in coal mining or deposits of sulfide rock in large quantities, which are exposed to water and oxygen [1]. AMD is a common problem in mining industry which if not handled properly can last long into the post-mining period. Contamination with AMD plays an important role in modifying natural channels ' physical, chemical, and biological character. Large amounts of metal ion and sulphate that flow into uncontaminated stream can cause the channel to degrade chemically. Although the concentration of toxic substances will diminish along the flow of water, AMD pollution will move to sediment in the river due to

Revised Manuscript Received on January 15, 2020.

* Correspondence Author

Fransiscus Benhardi Wastuwidya, Environmental Engineering Study Program, Civil Engineering Department, University of Indonesia, Depok, Indonesia. Email: fransiscus.wastuwidya@gmail.com

Setyo Sarwanto Moersidik*, Environmental Engineering Study Program, Civil Engineering Department, University of Indonesia, Depok, Indonesia. Email: ssarwanto@eng.ui.ac.id precipitation from these toxic elements and increase the potential for toxicity. Rivers affected by AMD can store heavy metals in sediments even though the water has a $\mathrm{pH}$ that is not too low and metal concentrations are low [2].

One of AMD's processing techniques is the phycoremediation method, which is Defined as the use of microalgae or macroalgae to extract and biotransform contaminants including nutrients and xenobiotics from flue gases in wastewater and $\mathrm{CO} 2$ along with the cultivation of algal biomass [3]. In general, removal of nutrients, heavy metals, and minerals in algae occur through the absorption and bioaccumulation mechanism. Along with the removal of elements from wastewater, algae will grow using these nutrients. Some elements will enter the cell surface, while others will be brought into the cell [4]

Phycoremediation technology in AMD is a developing field. Most research in this area uses microalgae for remediation of AMD indirectly, but combined with other technologies or utilizes dead algal biomass as biosorbent for heavy metal adsorption on AMD [4][5][6]. The drawback of AMD phycoremediation is limited by the growth rate of microalgae under acidic conditions. The growth rate limitations can reduce the effectiveness and efficiency of the remediation method, which makes other methods more feasible to be applied. In addition to an acidic environment, media with high heavy metal concentrations can damage microalgae cells, which causes inhibition of the microalgae growth [7].

Microalgae are known to be able to build resistance under acidic conditions and excessive heavy metal concentrations through the process of adaptation and acclimatization. Chlamydomonas acidophila microalgae strains were found in AMD ponds in disused copper mines with high acidity $(\mathrm{pH}$ 1.6) and high $\mathrm{PO}_{4}-\mathrm{P}$ concentrations, which indicate the adaptability of microalgae to extreme conditions. Another study shows microalgae colonies that built acid resistance present on an aquatic system affected by AMD [8], [9].

Microalgae acclimatization can be done by culturing microalgae in a controlled environment. A study was conducted to develop Scenedesmus dimorphus acid resistance through nonlethal exposure to acids. The study showed that Scenedesmus dimorphus were able to build acid resistance after being exposed to acidic media with ideal adaptive $\mathrm{pH}$ was $\mathrm{pH} 4.0$ and ideal adaptation time was 1 h.[10].

Botryococcus braunii is a green colonial planktonic alga and has been known for its ability to remove metal. Botryococcus braunii is

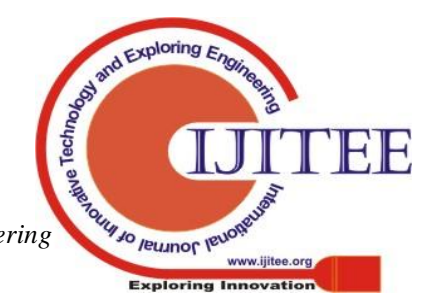


known as microalgae with slow growth, and for that reason, research on its ability on wastewater is limited and considered to be quite challenging.[11], [12].

The purpose of this study is to examine the ability to grow Botryococcus braunii acclimatized in the AMD environment so that AMD can be used as a growth medium for Botryococcus braunii while removing excess metals in AMD. In this study, the growth kinetics of Botryococcus braunii were examined, and also the response of Botryococcus braunii to different variations of AMD concentrations, based on the observed parameters. Growth rate determination is useful for evaluating cell growth, which can also be used to design large scale bioreactors. It is expected through the results obtained from this study, it can contribute to the problem of AMD using Botryococcus braunii.

\section{MATERIALS AND METHOD}

\section{A. Materials}

Botryoccocus braunii was collected from Surfactant and Bioenergy Research Center (SBRC) Institut Pertanian Bogor (IPB). Experiment was conducted using 5 photobioreactors (PBR) with capacity of 21 (10 cm diameter, $30 \mathrm{~cm}$ height). Aeration was given continuously using air (Resun Pump AC-9906). Two 21watt 1750 lumen LED (Philips T5 essential) was used as light source with 18:6 light:dark intervals. The AMD gold mine effluent, obtained from $\mathbf{J}$ Resources Bolaang Mongondow mining site, Sulawesi, Indonesia.

\section{B. Microalgae concentration determination}

Microalgae growth rate was determined by optical density at $680 \mathrm{~nm}$. Sample was diluted with aquadest to produce absorbance in the range of 0.1-1.0 and analyzed using UV-Vis Spectrophotometer (Shimadzu UV-1800). The solution was then filtered using Whatman filter paper No. 1 and dried using an oven for gravimetric analysis producing algal concentrations (g. $\left.\mathrm{L}^{-1}\right)$. Microalgae biomass are calculated using the equation [5], [10], [13]:

$$
\mathrm{DW}=\left(\mathrm{m}_{1}-\mathrm{m}_{2}\right) / \mathrm{V}
$$

where DW $\left(\mathrm{gr} \cdot \mathrm{L}^{-1}\right)$ is the biomass concentration $\mathrm{m}_{1}$ dan $\mathrm{m}_{2}$, is biomass weight before and after drying in gram $(\mathrm{g})$, respectively, and V is sample volume in litre (L). Results of optical density and microalgae concentration are plotted on a graph to find a linear relationship, which will be used as a basis for determining algal concentrations in solution. Botryoccocus braunii's relation between optical density and concentration of biomass was:

$$
y=1.5118 x-0.1216
$$

Specific growth rate $\mu\left(\mathrm{d}^{-1}\right)$ was calculated from the following equation [14]:

$$
\mu=\left(\ln \mathrm{N}_{2}-\ln \mathrm{N}_{1}\right) /(\mathrm{t} 2-\mathrm{t} 1)
$$

where $\mu\left(\mathrm{d}^{-1}\right)$ is specific growth rate, $\mathrm{N}_{1}$ and $\mathrm{N}_{2}$ is biomass concentration $\left(\mathrm{g} . \mathrm{L}^{-1}\right)$ on day $\mathrm{t}_{1}$ dan $\mathrm{t}_{2}$, respectively.

\section{Fe and Mn concentration determination}

Fe and Mn were analyzed with Logam Elmer - USA Analyst 800 Atomic Absorption Spectrophotometer (AAS). Removal efficiency was calculated using the [15]:

$$
\text { Removal Efficiency }=\left(\left(\mathrm{C}_{0}-\mathrm{C}_{\mathrm{t}}\right) / \mathrm{C}_{0}\right) \times 100 \%
$$

where $\mathrm{C}_{0}$ metal concentration on initial time $\left(\mathrm{t}_{0}\right)$ and $\mathrm{C}_{\mathrm{t}}$ is metal concentration on observed time $(t)$.

\section{Batch Cultivation}

Experiments were carried out by cultivating microalgae with different concentrations of AMD in each PBR, thus producing a medium with initial $\mathrm{pH}$ : 5.6, 5.1, 4.8, and 4.3. Nutrition is given through $2 \mathrm{~g} \mathrm{~N}$ : P: $\mathrm{K}$ fertilizer in each PBR. Control is given to the media without the addition of AMD and produces media with a $\mathrm{pH}$ of 7.2. The experiment was carried out for 14 days where everyday samples were taken to analyze optical density, $\mathrm{pH}$, and $\mathrm{Fe}$ and $\mathrm{Mn}$ concentration.

Table 1 Initial solution characterization of each PBR

\begin{tabular}{|c|c|c|c|c|}
\hline PBR & AMD addition $(v / v)$ & $\mathrm{Fe}\left(\mathrm{mg.} \mathrm{L}^{-1}\right)$ & $\mathrm{Mn}\left(\mathrm{mg} . \mathrm{L}^{-1}\right)$ & $\mathrm{pH}$ \\
\hline $\mathrm{A}$ & $0 \%$ & 1.86 & 0.37 & 7.2 \\
\hline B & $2.5 \%$ & 2.15 & 0.61 & 5.6 \\
\hline C & $3 \%$ & 2.47 & 0.67 & 5.1 \\
\hline D & $3.5 \%$ & 3.26 & 0.8 & 4.8 \\
\hline E & $4 \%$ & 3.82 & 0.92 & 4.3 \\
\hline
\end{tabular}

\section{RESULT}

Microalgae cultivation was conducted in 5 PBRs with AMD concentration variation, as shown in table (1) to understand its effect on Botryococcus braunii. As shown in table (2), Botryococcus braunii shows optimum growth rate in PBR B and C with maximum biomass of 1.352 g.L $\mathrm{L}^{-1}$ and $\mu$ of $0.143 \mathrm{~d}^{-1}$. In control, PBR microalgae showed lower growth, which is $0.0862 \mathrm{~d}^{-1}$. But at higher concentrations, as shown in PBR D and E, microalgae growth occurs more slowly and has lower productivity.

As shown in fig. 1(a), in PBR B and C the growth lag period of Botryococcus braunii is shorter compared to other PBRs, where an increase in growth occurs

on days 6-7. Meanwhile, microalgae on PBR D and E were inhibited, and there was a decrease in the biomass concentration on days 6-10 before having growth

increase on day 11. Changes in $\mathrm{pH}$, as shown in fig. 1 (b), increases to neutral on PBR B and C occur less than 48 hours, while changes in $\mathrm{pH}$ on PBR D and E occur more slowly at the start, but increase on day 4 and reach neutral $\mathrm{pH}$ on day five.

Fe and Mn were found present on all PBR, this is due to the presence of these two elements in the N: P: K fertilizer used as a source of nutrition. Each PBR showed differences in the removal efficiency of $\mathrm{Fe}$ 
content, with the highest removal efficiency of Fe at $84.29 \%$ in PBR E and the lowest at $6.92 \%$ in PBR B. There was a decrease in Mn concentrations in all batches up to below the measurement limit with removal efficiencies above $90 \%$ for all PBRs. This shows that $\mathrm{Mn}$ is an element essential for Botryococcus braunii to grow.

The specific growth rate calculated using equation (3) shows the best Botryococcus braunii growth possessed by Botryococcus braunii in PBR B, followed by PBR C, A, D and $\mathrm{E}$.

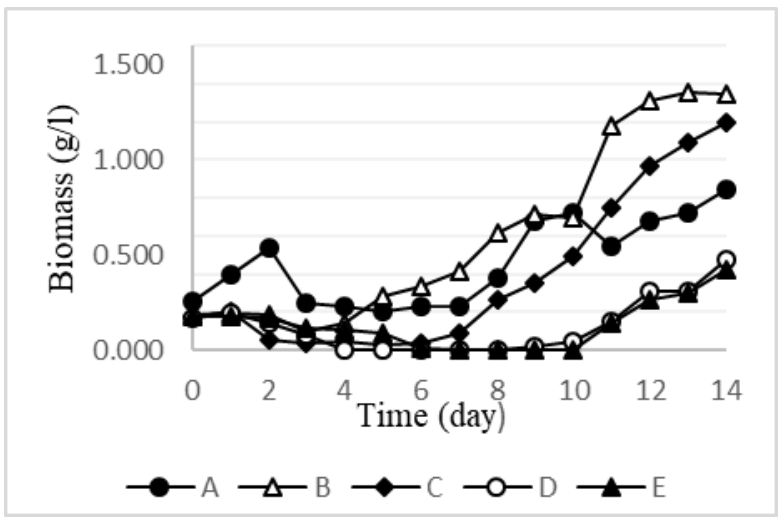

Mn. Botryococcus braunii showed different growth rate sequentially from the PBR with the highest rate of PBR B, C, A, D, E with $\mu$ value of $1.403 \mathrm{~d}^{-1}, 1.374 \mathrm{~d}^{-1}, 0.0862 \mathrm{~d}^{-1}, 0.0738$ $\mathrm{d}^{-1}$, and $0.0616 \mathrm{~d}^{-1}$, respectively. This indicates concentration of this element affecting its growth rate. There is a tolerance limit of the metal content of $\mathrm{Fe}$ and $\mathrm{Mn}$ which can stimulate the growth of microalgae, and if it exceeds that value it can limit its growth. Decrease in $\mathrm{Fe}$ and $\mathrm{Mn}$ concentrations shows that $\mathrm{Fe}$ and $\mathrm{Mn}$ are essential elements for microalgae growth [16]. In this study, it was found that maximum

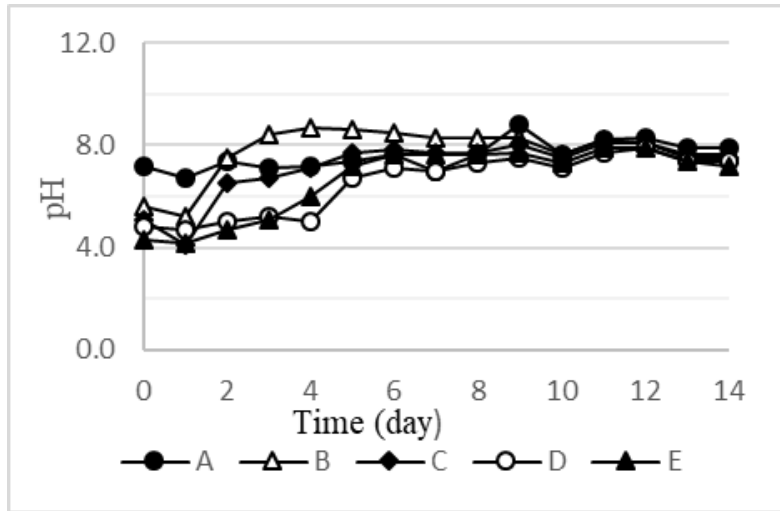

Figure 1. Changes in biomass concentration (a) and pH (b) in Botryococcus braunii culture with variations in AMD concentration

Table 2. Changes in $\mathrm{pH}, \mathrm{Fe}, \mathrm{Mn}$ concentration and specific growth rate

\begin{tabular}{|c|c|c|c|c|c|c|c|c|c|}
\hline \multirow{2}{*}{ PBR } & \multicolumn{2}{|c|}{ pH } & \multicolumn{2}{|c|}{$\mathrm{Fe}\left(\mathrm{mg} . \mathrm{L}^{-1}\right)$} & \multirow{2}{*}{$\begin{array}{l}\text { Removal } \\
\text { efficiency }\end{array}$} & \multicolumn{2}{|c|}{$\operatorname{Mn}\left(\right.$ mg.L $\left.^{-1}\right)$} & \multirow{2}{*}{$\begin{array}{c}\text { Removal } \\
\text { efficiency } \\
(\%)\end{array}$} & \multirow{2}{*}{$\underset{\left(\mathbf{d}^{-1}\right)}{\boldsymbol{\mu}}$} \\
\hline & $\mathbf{t}_{1}$ & $\mathbf{t}_{14}$ & $t_{1}$ & t14 & & $\mathbf{t}_{1}$ & $\mathbf{t}_{14}$ & & \\
\hline A & 7.2 & 7.9 & 1.86 & 1.34 & 27.96 & 0.37 & $<0.023$ & $>94$ & 0.0862 \\
\hline B & 5.6 & 7.6 & 2.15 & 2 & 6.98 & 0.61 & $<0.023$ & $>96$ & 0.1403 \\
\hline $\mathrm{C}$ & 5.1 & 7.5 & 2.47 & 1.2 & 51.42 & 0.67 & $<0.023$ & $>97$ & 0.1374 \\
\hline $\mathrm{D}$ & 4.8 & 7.4 & 3.26 & 0.67 & 79.45 & 0.8 & $<0.023$ & $>97$ & 0.0738 \\
\hline $\mathrm{E}$ & 4.3 & 7.2 & 3.82 & 0.6 & 84.29 & 0.92 & $<0.023$ & $>98$ & 0.0616 \\
\hline
\end{tabular}

\section{DISCUSSIONS}

Microalgae show the ability to adapt to acidic conditions with different metal contents and this

affects its metabolism. Previous study showed microalgae had a capacity for pH-buffering. This is known to happen in conjunction with its photosynthesis cycle [10], [12]. This $\mathrm{pH}$-buffering ability varied across various microalgae species. In addition, it is also known that $\mathrm{Fe}$ and $\mathrm{Mn}$ are essential elements for microalgae growth. In this study, it was found that higher concentrations of AMD resulted in a longer lag period in microalgae growth. The increase in microalgae growth occurs at $\mathrm{pH} 7.0$, where the $\mathrm{pH}$ supports the growth of microalgae. Based on these observations, it can be concluded that the growth of microalgae occurs along with its ability to neutralize acids. The increase in $\mathrm{pH}$ caused by photosynthesis activity causes changes in media conditions to be more suitable for microalgae growth [10], [12].

Aside from being influenced by $\mathrm{pH}$, the growth of microalgae is also influenced by the concentration of $\mathrm{Fe}$ and growth was obtained in microalgae with an initial $\mathrm{pH}$ of 5.6, and $\mathrm{Fe}$ and $\mathrm{Mn}$ concentrations of 2.15 and 0.62 , respectively.

At the end of the observation, it was found that a higher decrease in Fe concentration in PBR D and E. The difference in Fe uptake was alleged as a result of the acclimatization of Botryococcus braunii in batches D and $\mathrm{E}$ so that it has a higher removal efficiency. This is possible due to the metabolism of Botryococcus braunii in high metal conditions so that Botryococcus braunii produces extracellular polymeric substances (EPS) which can absorb metals in the environment and also produce metal precipitate [6], [17], however, this needs to be proven in further study.

\section{CONCLUSION}

This study was conducted to determine the ability of Botryococcus braunii to grow on media with different AMD concentrations. The highest growth of Botryococcus braunii was found in media with an initial $\mathrm{pH}$ of 5.6, and Fe and $\mathrm{Mn}$ concentrations of $2.15 \mathrm{mg} . \mathrm{L}^{-1}$ and $0.62 \mathrm{mg} . \mathrm{L}^{-1}$, respectively.

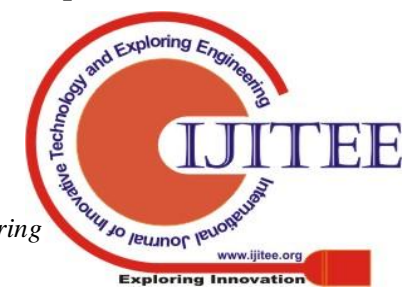


Also known is the adaptability of Botryococcus braunii under acidic conditions and high Fe and Mn metal content, where Botryococcus braunii plays a role in increasing the $\mathrm{pH}$ of the media and is able to absorb Fe and Mn so that it can make AMD as a growing medium for Botryococcus braunii.

\section{ACKNOWLEDGMENT}

PITTA University of Indonesia financially supported this research with contract number NKB-0784/UN2.R3.1/HKP.05.00/2019.

\section{REFERENCES}

1. K. K. Kefeni, T. A. M. Msagati, and B. B. Mamba, "Acid mine drainage: Prevention, treatment options, and resource recovery: A review," J. Clean. Prod., vol. 151, pp. 475-493, 2017.

2. A. M. Sarmiento, A. DelValls, J. M. Nieto, M. J. Salamanca, and M. A. Caraballo, "Toxicity and potential risk assessment of a river polluted by acid mine drainage in the Iberian Pyrite Belt (SW Spain)," Sci. Total Environ., vol. 409, no. 22, pp. 4763-4771, 2011.

3. I. Rawat, R. Ranjith Kumar, T. Mutanda, and F. Bux, "Dual role of microalgae: Phycoremediation of domestic wastewater and biomass production for sustainable biofuels production," Appl. Energy, vol. 88, no. 10, pp. 3411-3424, 2011.

4. J. K. Bwapwa, A. T. Jaiyeola, and R. Chetty, "Bioremediation of acid mine drainage using algae strains: A review," South African J. Chem. Eng., vol. 24, no. April, pp. 62-70, 2017.

5. H. Choi and S. Lee, "Heavy metal removal from acid mine drainage by calcined eggshell and microalgae hybrid system," vol. 3, pp. 13404-13411, 2015.

6. A. Mantzorou, E. Navakoudis, K. Paschalidis, and F. Ververidis, "Microalgae: a potential tool for remediating aquatic environments from toxic metals," Int. J. Environ. Sci. Technol., vol. 15, no. 8, pp. 1815-1830, 2018

7. B. K. Das, A. Roy, S. Singh, and J. Bhattacharya, "Eukaryotes in acidic Mine Drainage environments: Potential applications in bioremediation," Rev. Environ. Sci. Biotechnol., vol. 8, no. 3, pp. 257-274, 2009.

8. A. P. P. Freitas, I. A. H. Schneider, and A. Schwartzbold, "Biosorption of heavy metals by algal communities in water streams affected by the acid mine drainage in the coal-mining region of Santa Catarina state, Brazil," Miner. Eng., vol. 24, no. 11, pp. 1215-1218, 2011.

9. A. P. Dean et al., "Metabolic adaptation of a Chlamydomonas acidophila strain isolated from acid mine drainage ponds with low eukaryotic diversity," Sci. Total Environ., vol. 647, pp. 75-87, 2019.

10. Y. Jiang, X. Peng, W. Zhang, and T. Liu, "Enhancement of acid resistance of Scenedesmus dimorphus by acid adaptation,” J. Appl. Phycol., vol. 24, no. 6, pp. 1637-1641, 2012.

11. P. Gani, N. Mohamed Sunar, H. Matias-Peralta, A. A. Abdul Latiff, U. K. Parjo, and A. A. Oyekanmi, "Green Approach in the Bio-removal of Heavy Metals from wastewaters," MATEC Web Conf., vol. 103, pp. 1-8, 2017.

12. M. M. Areco, E. Haug, and G. Curutchet, "Studies on bioremediation of Zn and acid waters using Botryococcus braunii," J. Environ. Chem. Eng., vol. 6, no. 4, pp. 3849-3859, 2018.

13. P. B. Asthary, Y. Setiawan, A. Surachman, and , S., "Pertumbuhan Mikroalga Spirulina platensis Dalam Efluen Industri Kertas,” J. Selulosa, vol. 3, no. 02, pp. 97-102, 2016.

14. R. R. L. Guillard, Division rate. In: Stein J (ed) Handbook of phycological methods: culture methods and growth measurements. Cambridge: Cambridge University Press, 1973.

15. APHA (American Public Health Association), Standard Methods for the Examination of Water and Wastewater, 20th ed. Washington D.C. American Public Health Association/American Water Works Association/Water Environment Federation, 1998.

16. Y. T. Park, H. Lee, H. S. Yun, K. G. Song, S. H. Yeom, and J. Choi, "Removal of metal from acid mine drainage using a hybrid system including a pipes inserted microalgae reactor," Bioresour. Technol., vol. 150, pp. 242-248, 2013.

17. R. Xiao and Y. Zheng, "Overview of microalgal extracellular polymeric substances (EPS) and their applications,” Biotechnol. Adv., vol. 34, no. 7 pp. 1225-1244, 2016.

\section{AUTHORS PROFILE}
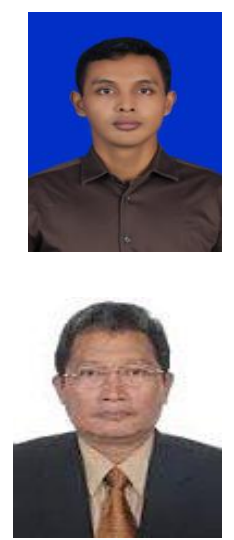

Fransiscus Benhardi Wastuwidya, received his Bachelor of Agriculture Technology degree in Agriculture Engineering from Universitas Gadjah in 2015. After graduating from his bachelor degree, he joined PT Green Planet Indonesia where he worked as supervisor for mining rehabilitation activity to supervise mining rehabilitation team. He was currently a Master student in Universitas Indonesia.

Setyo Sarwanto Moersidik, is currently a lecturer at the environmental engineering department, Universitas Indonesia. Completed his $\mathrm{PhD}$ from University of Montpellier, France. He presented many papers in International Conferences. Also published several research articles in Scopus index Journal. 